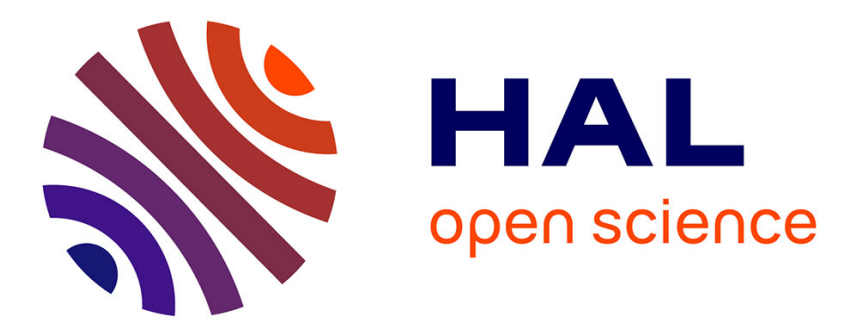

\title{
Water, carbon and nitrogen cycling in a rendzina soil cropped with winter oilseed rape: the Châlons Oilseed Rape Database
}

\author{
Ghislain Gosse, Pierre Cellier, Pascal Denoroy, Benoit Gabrielle, Patricia
} Laville, Bruno Leviel, Eric Justes, Bernard Nicolardot, Bruno Mary, Sylvie Recous, et al.

\section{To cite this version:}

Ghislain Gosse, Pierre Cellier, Pascal Denoroy, Benoit Gabrielle, Patricia Laville, et al.. Water, carbon and nitrogen cycling in a rendzina soil cropped with winter oilseed rape: the Châlons Oilseed Rape Database. Agronomie, 1999, 19 (2), pp.119-124. hal-00885919

\section{HAL Id: hal-00885919 https://hal.science/hal-00885919}

Submitted on 1 Jan 1999

HAL is a multi-disciplinary open access archive for the deposit and dissemination of scientific research documents, whether they are published or not. The documents may come from teaching and research institutions in France or abroad, or from public or private research centers.
L'archive ouverte pluridisciplinaire HAL, est destinée au dépôt et à la diffusion de documents scientifiques de niveau recherche, publiés ou non, émanant des établissements d'enseignement et de recherche français ou étrangers, des laboratoires publics ou privés. 


\title{
Water, carbon and nitrogen cycling in a rendzina soil cropped with winter oilseed rape: the Châlons Oilseed Rape Database
}

\author{
Ghislain Gosse ${ }^{a}$, Pierre Cellier ${ }^{\mathrm{a}}$, Pascal Denoroy ${ }^{\mathrm{a}}$, Benoît Gabrielle ${ }^{\mathrm{a}^{*}}$, Patricia Laville ${ }^{\mathrm{a}}$, \\ Bruno Leviel $^{\mathrm{a}}$, Eric Justes ${ }^{\mathrm{b}}$, Bernard Nicolardot ${ }^{\mathrm{b}}$, Bruno Mary ${ }^{\mathrm{c}}$, Sylvie Recous ${ }^{\mathrm{c}}$, \\ Jean-Claude Germon ${ }^{\mathrm{d}}$, Catherine Hénault ${ }^{\mathrm{d}}$, P.K. Leech ${ }^{\mathrm{e}}$ \\ ${ }^{a}$ Unité de recherche en bioclimatologie, Inra, 78850 Thiverval-Grignon, France \\ ${ }^{\mathrm{b}}$ Station d'agronomie de Châlons-Reims, Inra, Reims, France \\ 'Station agronomique de l'Aisne, Inra, Laon, France \\ ${ }^{\mathrm{d}}$ Laboratoire de microbiologie des sols, Inra, Dijon, France \\ ${ }^{\text {e }}$ Department of Soil Science (B), Institute of Arable Crops Research, Rothamsted, Harpenden, UK
}

(Received 15 September 1998; accepted 26 January 1999)

\begin{abstract}
The Châlons Oilseed Rape Database holds the results of a comprehensive experiment on the dynamic fluxes of water, carbon and nitrogen within a soil-crop system at the field-scale, conducted in the Champagne region in France. The Châlons experiment started with the sowing of a rapeseed crop (Brassica napus L.) in September 1994, and stopped at its harvest in July 1995. It involved three fertilizer N treatments and a bare control. The soil was a rendzina overlying a subsoil of mixed compact and cryoturbed chalk. The variables monitored were: crop biomass, $\mathrm{C}$ and $\mathrm{N}$ content, soil matric potential, water and mineral $\mathrm{N}$ contents, actual evapotranspiration, nitrous oxide emissions, and ammonia volatilization, along with the usual meteorological data. Mass-balance estimates of water drainage and $\mathrm{NO}_{3}$ leaching below the root-zone, along with ${ }^{15} \mathrm{~N}$ balances accounting for the short-term dynamics of fertilizer $\mathrm{N}$ are also available. The data are accessible on the Internet through a World Wide Web server by means of a specific frontend, and may be used to test or calibrate soil-crop models. (@ Inra/Elsevier, Paris.)
\end{abstract}

Internet database / nitrogen cycle / rendzina / oilseed rape

Résumé - Une base de données sur les cycles des éléments eau, carbone et azote dans un sol de rendzine sous culture de colza. La base de données CORD (Châlons Oilseed Rape Database) archive les résultats d'une expérience intensive conduite en région Champagne sur la dynamique des flux d'eau, de carbone et d'azote dans un système sol-plante, à l'échelle de la parcelle agricole. L'expérience a débuté au semis d'une culture de colza (Brassica napus L.) en sep-

Communicated by Jim Douglas (Penicuik, UK)

* Correspondence and reprints

gabriele@bcgn.grignon.inra.fr 
tembre 1994, et a duré jusqu'à la récolte de celui-ci en juillet 1995. Trois traitements azotés, ainsi qu'un témoin en sol nu ont été suivis, et le sol était une rendzine sur craie à poches de cryoturbation. Les variables mesurées comprennent : biomasse et contenu en carbone et azote de la culture, profils de potentiel matriciel, d'humidité et d'azote minéral du sol, évapotranspiration réelle, émissions d'oxyde nitreux et volatilisation d'ammoniac, ainsi que les variables climatiques usuelles. De plus, le drainage et le lessivage de nitrate sous la zone racinaire ont été estimés par défaut de bilan. Enfin des bilans à l'azote marqué ont permis de rendre compte du devenir de l'engrais sur des pas de temps courts. Les données sont accessibles sur un serveur internet par l'intermédiaire d'une interface spécifique, et peuvent par exemple servir au test ou au calage de modèles de simulation des systèmes sol-culture. (@ Inra/Elsevier, Paris.)

\section{base de données internet / cycle de l'azote / rendzine / colza}

\section{INTRODUCTION}

Within the European Union, the recent implementation of the reformed Common Agricultural Policy prompted cultivation of oilseed rape (OSR) for biofuel production on set-aside land. Because of the large fertilizer requirements of OSR, in particular of nitrogen $(\mathrm{N})$, concerns were raised as to the environmental impacts of such a practice which could be expected to lead to substantial $\mathrm{N}$ losses either to groundwater through $\mathrm{NO}_{3}$ leaching, or to the atmosphere as ammonia $\left(\mathrm{NH}_{3}\right)$ or nitrous oxide $\left(\mathrm{N}_{2} \mathrm{O}\right)$. However, data on such $\mathrm{N}$ budgets are scant for OSR, because direct measurements are timeconsuming and expensive, especially concerning gaseous losses.

Deterministic models of the water, carbon (C) and $\mathrm{N}$ cycles within the soil-crop system offer an attractive alternative to analyse these pollution fluxes. They may provide estimates of the risks associated with climate variability, allowing us to test various crop management options when run on a longterm series of past or generated weather data. However, the accuracy of their predictions relies primarily on the range of experimental data against which they have been calibrated, and the data often do not provide sufficient information to test separately the simulation of each process involved in the $\mathrm{N}$ cycle.

With the objectives of i) measuring dynamic water, $\mathrm{C}$ and $\mathrm{N}$ budgets for an OSR crop subjected to different levels of fertilizer $\mathrm{N}$, and ii) testing several soil-crop models against a comprehensive data set, we set up a 1-year experiment near Châlons-enChampagne $(48.50 \mathrm{~N} ; 2.15 \mathrm{E})$ in north-eastern
France. Monitored variables included: profiles of soil hydraulic suction, water and $\mathrm{N}$ contents in $30 \mathrm{~cm}$ layers down to $120 \mathrm{~cm}$, dry matter (DM) and $\mathrm{C}-\mathrm{N}$ contents of the main plant parts (roots, stems, leaves, pods and grains), rooting dynamics, and ${ }^{15} \mathrm{~N}$ balances following the application of labelled fertilizer $\mathrm{N}$ in microplots, along with basic climatic data. Soil parameters such as microbial biomass, bulk density, hydraulic conductivity and water retention curves were also measured. Compared to other similar data sets (albeit for wheat [2, 4]), ours also includes field-measurements of $\mathrm{NH}_{3}$ volatilization and $\mathrm{N}_{2} \mathrm{O}$ emissions, using chamber or micrometeorological techniques. The data were organized into the Châlons Oilseed Rape Database (CORD), for which an HTML-based interface was developed, and made accessible through the Internet on a dedicated Web site.

\section{DESCRIPTION AND QUALITY OF THE DATA}

The $\mathrm{N}$ treatments were: no fertilizer (N0), split spring application of $135 \mathrm{~kg} \mathrm{~N} \mathrm{ha}{ }^{-1}(\mathrm{~N} 1)$, and spring and autumn application of $270 \mathrm{~kg} \mathrm{~N}^{-1}$ (N2), along with a bare control soil. They were established on $30 \mathrm{~m} \times 30 \mathrm{~m}$ blocks arranged in a split-plot design with three replicates, and also on 1-ha plots dedicated to the micrometeorological measurements. Crops were sown on 9 September 1994, and harvested on 11 July 1995. The soil was a grey rendzina, consisting of a $30-\mathrm{cm}$ deep loamytextured calcareous topsoil overlying a $60-\mathrm{cm}$ thick zone of cryoturbed chalk, lying in turn over a 
bedrock made of layered horizontal chalk plaques. Table I lists the available properties for this soil.

Table II lists the dynamic variables measured, along with the timing of their measurement and the methods employed. These are further detailed in refs. [16] and [11].

Soil cores were taken for water and mineral $\mathrm{N}$ analyses using an automatic auger (Hydrocare, MCL2, Geonor, Norway) with a diameter of $15 \mathrm{~mm}$. In each block, eight 120 -cm-deep cores were collected every metre along a straight line and divided into four $30-\mathrm{cm}$ layers. For each layer, the eight replicate samples were pooled before analysis. Surface soil moisture was also continuously monitored using sets of time domain reflectometry (TDR) probes wired to a datalogger (CR 10, Campbell Sci., UK). Probes were horizontally placed at depths of 5, 10, 20 and $45 \mathrm{~cm}$, and calibrated against gravimetric measurements on handcollected soil samples coupled with bulk density values obtained using a gamma densitometer (LPCInra, Angers, France) on the same spot. The datalogger also recorded the soil suction values given by sets of tensiometers on a hourly basis, during the winter drainage period. Two of the four TDR probes were paired with tensiometers, which allowed us to determine the retention curves in the rendzina $(-20 \mathrm{~cm})$ and in the chalky zone underneath $(-45 \mathrm{~cm})$. The saturated hydraulic conductivity in the rendzina was measured at two depths $(-10$ and $-20 \mathrm{~cm}$ ) using a Guelph infiltrometer (Soil Moisture, Santa Barbara, USA).

Total denitrification was not directly measured, but its magnitude appeared to be limited. First, the levels of $\mathrm{N}_{2} \mathrm{O}$ emissions recorded were very low (less than $2{\mathrm{~g} \mathrm{~N}-\mathrm{N}_{2} \mathrm{O} \mathrm{ha}}^{-1}$ day $^{-1}$ ), and the continuous monitoring of surface soil water showed that the water-filled pore space rarely exceeded the threshold value of $60 \%$ that is generally considered conducive to denitrification [14]. Second, the semideterministic denitrification model NEMIS [13] gave an estimate of $1 \mathrm{~kg} \mathrm{~N} \mathrm{ha}^{-1}$ year $^{-1}$ for total denitrification over the growing season. NEMIS was run on a daily basis with the measured surface $(0-30 \mathrm{~cm})$ soil water, temperature and $\mathrm{NO}_{3}$ content as inputs. The model was also provided with a potential denitrification rate which had been measured in the laboratory on undisturbed topsoil cores injected with acetylene.

Lastly, as regards gaseous losses, the micrometeorological campaigns were carried out for 2-3 weeks after fertilizer spreading.

Replicate micro-plots $\left(0.36 \mathrm{~m}^{2}\right.$ in area) labelled with ${ }^{15} \mathrm{~N}$ at 3.2 atom $\%$ excess were also set up for the N2 treatment, and dynamically sampled 3-4 times after each fertilizer application. The following fractions were analysed for isotopic excess: soil inorganic $\mathrm{N}\left(\mathrm{NO}_{3}^{-}\right.$and $\left.\mathrm{NH}_{4}^{+}\right)$, soil organic $\mathrm{N}$, with four layers down to $90 \mathrm{~cm}$, and plant $\mathrm{N}$ (with a breakdown into the main parts at harvest).

Table 1. Measured soil properties available in the CORD, for each soil layer. Layers are numbered from 1 to 4 , starting from the surface downwards in $30-\mathrm{cm}$ increments.

\begin{tabular}{|c|c|c|}
\hline Property and Unit & Available for layer(s) & Method \\
\hline Bulk Density $\left(\mathrm{g} \mathrm{cm}^{-3}\right)$ & $1-4$ & gravimetric \\
\hline Hydraulic conductivity $\left(\mathrm{m} \mathrm{s}^{-1}\right)$ & $1-2$ & Guelph infiltrometer \\
\hline Soil retention curve & $1-2$ & tensiometers coupled with TDR probes \\
\hline Microbial biomass (C, $\left.\mathrm{mg} \mathrm{kg}^{-1}\right)$ & 1 & fumigation-extraction \\
\hline Residues in soil at sowing $\left(\mathrm{tC} \mathrm{ha}{ }^{-1}\right)$ & 1 & fractionation and floatation $(\geq 80 \mu \mathrm{m})$ \\
\hline Particle-size distribution ( \%) & $1-4$ & measured after removal of carbonates \\
\hline Field-capacity content $(\%)$ & $1-4$ & pressure plates* \\
\hline Soil C, N, $\mathrm{CaCO}_{3}, \mathrm{pH}$ & $1-4$ & ${ }^{+}$Afnor standards NF X $31-109,31-111,31-105$, and $31-103$ \\
\hline
\end{tabular}

* For layers 2-4, field-capacity estimates for similar soils were used.

+Association Française de Normalisation. Tour Europe, cedex 7, 92080 Paris-la-Défense 
Table II. Dynamic measurements conducted in the Châlons experiment: type, method and timing. Timing includes the duration and the frequency of the measurements.

\begin{tabular}{|c|c|c|}
\hline Measurement and unit & Timing & Method \\
\hline \multicolumn{3}{|c|}{ - Meteorological and soil temperature data } \\
\hline Rainfall & hourly & automatic tipping bucket gauge \\
\hline Air temperature & hourly & thermocouples \\
\hline Wind speed & hourly & opto-electronic cup anemometer \\
\hline Water vapour pressure & hourly & capacitive moisture probe \\
\hline \multicolumn{3}{|l|}{ - Soil $N$ balance } \\
\hline $\begin{array}{l}\text { Soil mineral } \mathrm{N}\left(\mathrm{NO}_{3}^{-} \text {and }\right. \\
\left.\mathrm{NH}_{4}^{+}\right)\left(\mathrm{mg} \mathrm{N} \mathrm{kg}^{-1} \text { soil }\right)\end{array}$ & $\begin{array}{l}\text { every } 2-3 \text { weeks } \\
9 / 94-7 / 95\end{array}$ & $\begin{array}{l}\text { soil core sampling + auto-analyser } \\
\text { (Skalar, Breda, NL) }\end{array}$ \\
\hline $\begin{array}{l}\mathrm{N}_{2} \mathrm{O} \text { emissions } \\
\left(\mathrm{g}^{\mathrm{N}} \text { ha }^{-1} \text { day }^{-1}\right)\end{array}$ & $\begin{array}{l}\text { every } 1-3 \text { weeks } \\
9 / 94-7 / 95\end{array}$ & $\begin{array}{l}0.2-\mathrm{m}^{2} \text { static chambers + gas chromatography } \\
(\text { Varian } 3400 \mathrm{Cx})\end{array}$ \\
\hline $\begin{array}{l}\mathrm{NH}_{3} \text { volatilization } \\
\left(\mathrm{g} \mathrm{N} \mathrm{ha}^{-1} \text { day }^{-1}\right)\end{array}$ & $\begin{array}{l}\text { hourly } \\
15-27 / 9 / 94,15-28 / 2 / 95,14-27 / 3 / 95\end{array}$ & $\begin{array}{l}\text { micrometeorological gradient technique } \\
\text { chemo-luminescence } \mathrm{NH}_{3} \text { analyser } \\
\text { (NH30M, Environnement SA, Poissy, F) }\end{array}$ \\
\hline $\begin{array}{l}\mathrm{NO}_{3}^{-} \text {leaching } \\
\left(\mathrm{kg}^{\mathrm{N}} \text { ha }^{-1} \text { day }^{-1}\right)\end{array}$ & $\begin{array}{l}\text { every } 1-3 \text { weeks } \\
9 / 94-7 / 95\end{array}$ & $\begin{array}{l}\text { estimates obtained by multiplying water drainage } \\
\text { with } \mathrm{NO}_{3} \text { concentration in bottom layer of soil }\end{array}$ \\
\hline \multicolumn{3}{|l|}{ - ${ }^{15} \mathrm{~N}$ balances } \\
\hline Soil N: & $\begin{array}{l}\text { every week for } 4 \text { weeks } \\
\text { after fertilizer application }\end{array}$ & \\
\hline $\begin{array}{l}- \text { total } \mathrm{N} \\
\mathrm{kg} 15 \mathrm{~N} \text { ha }\end{array}$ & & $\begin{array}{l}\text { flash combustion (C-N analyser ANA 1500) } \\
+ \text { mass spectrometry (VG SIRA 9) }\end{array}$ \\
\hline $\begin{array}{l}- \text { inorganic } \mathrm{N} \\
\mathrm{kg} 15 \mathrm{~N} \mathrm{ha}\end{array}$ & & $\begin{array}{l}\text { extraction with } 1 \mathrm{M} \mathrm{KCl} \text {, steam distillation } \\
+ \text { mass spectrometry }\end{array}$ \\
\hline $\begin{array}{l}\text { Plant } \mathrm{N} \\
\mathrm{kg} 15 \mathrm{~N} \mathrm{ha}^{-1}\end{array}$ & $\begin{array}{l}\text { every week for } 4 \text { weeks } \\
\text { after fertilizer application }\end{array}$ & $\begin{array}{l}\text { flash combustion (C-N analyser ANA 1500) } \\
+ \text { mass spectrometry }\end{array}$ \\
\hline \multicolumn{3}{|l|}{ - Soil water balance } \\
\hline $\begin{array}{l}\text { Water content }\left(\mathrm{g} \mathrm{g}^{-1} \text { soil }\right) \\
\left(\mathrm{cm}^{3} \mathrm{~cm}^{-3} \text { soil }\right)\end{array}$ & $\begin{array}{l}\text { every } 2-3 \text { weeks } \\
9 / 94-7 / 95\end{array}$ & soil core sampling + oven-drying \\
\hline & $\begin{array}{l}\text { hourly } \\
9 / 94-6 / 95\end{array}$ & $\begin{array}{l}\text { time domain reflectometry } \\
\text { (Tektronix, USA) }\end{array}$ \\
\hline $\begin{array}{l}\text { Matric suction } \\
(\mathrm{cm} \text { water) }\end{array}$ & $\begin{array}{l}\text { hourly } \\
11 / 94-5 / 95\end{array}$ & $\begin{array}{l}\text { tensiometers }+ \text { pressure transducers } \\
\text { (Soil Moisture, Santa Barbara, USA) }\end{array}$ \\
\hline $\begin{array}{l}\text { Actual évapo-transpiration } \\
\left(\text { AET, } \mathrm{mm} \mathrm{h}^{-1}\right)\end{array}$ & $\begin{array}{l}\text { hourly } \\
15-27 / 9 / 94,15-28 / 2 / 95,14-27 / 3 / 95^{*}\end{array}$ & energy balance + gradient technique \\
\hline \multicolumn{3}{|l|}{ - Crop $C-N$ balance } \\
\hline Dry matter $\left(\mathrm{t} \mathrm{ha}^{-1}\right)$ & $\begin{array}{l}\text { every } 2-3 \text { weeks } \\
9 / 94-7 / 95\end{array}$ & $\begin{array}{l}\text { sampling of } 1.5-\mathrm{m}^{2} \text { plots }+ \text { separation into main } \\
\text { parts + oven-drying }\left(80^{\circ} \mathrm{C}\right)\end{array}$ \\
\hline $\begin{array}{l}\text { C-N concentration } \\
\left(\mathrm{g} \mathrm{N} \mathrm{g}^{-1} \mathrm{DM}\right)\end{array}$ & $\begin{array}{l}\text { every } 2-3 \text { weeks } \\
9 / 94-7 / 95\end{array}$ & $\begin{array}{l}\text { Dumas method in dried tissues } \\
\text { (ANA } 1500 \text {, Carlo-Erba, It.) }\end{array}$ \\
\hline $\begin{array}{l}\text { Leaf and pod area indices } \\
\left(\mathrm{m}^{2} \mathrm{~m}^{-2}\right)\end{array}$ & $\begin{array}{l}\text { every } 2-3 \text { weeks } \\
9 / 94-7 / 95\end{array}$ & $\begin{array}{l}\text { optical planimeter } \\
\text { (Licor 5000, USA) }\end{array}$ \\
\hline Rooting depth $(\mathrm{cm})$ & $\begin{array}{l}\text { every month } \\
9 / 94-7 / 95\end{array}$ & in situ root mapping through a $2-\mathrm{cm}-\mathrm{mesh}$ grid \\
\hline $\begin{array}{l}\text { Frequency of root } \\
\text { occupation }(\%)\end{array}$ & $\begin{array}{l}\text { every month } \\
9 / 94-7 / 95\end{array}$ & in situ mapping of root \\
\hline
\end{tabular}

* Daily AET data for the 9/94-7/95 period were interpolated using Ritchie's model [17]. 
The root length density, which is a common parameter in models of crop water transpiration and $\mathrm{N}$ uptake, was not directly measured. However, it may be related to the frequency of lateral occupation by the roots cited in table II [9]. Indirect estimates of water drainage and $\mathrm{NO}_{3}$ leaching below the root zone, and of net $\mathrm{N}$ mineralization are available in the database as calculated from mass balances [16]. In the crop budget, the return of $\mathrm{N}$ to the soil as leaf litter resulting from senescence appeared to be an important item, as estimated by frequently sampling the dead material on plastic grids placed on the soil surface at the base of the canopy.

As to the accuracy of the data, most of the replicated measurements presented in table II had acceptable standard deviations with typical coefficients of variation of $10 \%$ for soil moisture, and $15 \%$ for the soil inorganic $\mathrm{N}$ or plant biomass and $\mathrm{N}$. The confidence intervals were somewhat larger for the statistics on rooting dynamics derived from root mapping, although these were performed over nine planting rows, because of subsoil heterogeneity. The static $\mathrm{N}_{2} \mathrm{O}$ measurements were also quite variable, essentially due to the weak values of the fluxes, but the high number of replicates (eight) enabled us to detect a significant effect of fertilization on the $\mathrm{N}_{2} \mathrm{O}$ emissions.

\section{EXAMPLES OF USE}

As stated in the introductory objectives, the CORD first provided figures to quantify the effect of $\mathrm{N}$ fertilization on $\mathrm{N}$ losses from OSR crops during the growing season [8]. It has also proved to be a unique data set for testing the various components of soil-crop models, such as a modified version of the CERES model [10], the mechanistic DAISY model [12] and the Rothamsted $\mathrm{C}-\mathrm{N}$ model SUNDIAL [1]. The CORD made it possible to screen the weaknesses and strengths in these models, and to identify potential improvements to them [6]. Given the range of measured soil parameters, different parameterization scenarios could also be implemented to analyse model sensitivity to the level of information available for the simulation [5]. In gen- eral, it appears that a wide range of soil-crop models could be tested on this data set with benefits as regards the simulation of separate processes. As a global validation data set the CORD is somewhat limited because it relates only to one soil and covers less than a year. However, its time span should soon be extended with the addition of results from an extra 8-month experiment following the harvest of OSR from the same field. During this period, soil cover consisted of OSR volunteers and bare soil, and measurements of OSR residue decomposition and soil microbial respiration were also carried out.

From the point of view of crop modelling, the CORD was used to develop a CERES-type model for OSR, including the processes of leaf senescence and the effect of a limited soil $\mathrm{N}$ supply on photosynthesis and leaf and pod elongation $[3,7]$. The resulting model, CERES-Rape, is scheduled to be integrated into the international decision support system DSSAT [15]. The effect of $\mathrm{N}$ nutrition on the radiation use efficiency of the canopy is also under investigation on the basis of additional chemical analyses of plant composition.

\section{DATA ACCESS}

Data in CORD may be searched, extracted and downloaded on a dedicated Internet World Wide Web server, whose address is:

http://www-bioclim.grignon.inra.fr/ecobilan/base/accueil.html

After connecting to this site, the user may select the data required using either a Hypertext menu-driven interface, which also provides a few information pages about the CORD, or a version of the database developed under the statistical software 'Splus', which features additional statistical and graphical outputs. The latter may be remotely used in a telnet session, or locally after downloading as described on the Web pages.

In both versions, data are sorted in a tree structure that starts from main classes such as soil water, meteorological data or gaseous fluxes, and progressively narrows down to an ultimate class of data (e.g. grain $\mathrm{N}$ content), for which various statistics 
are proposed prior to downloading. Hypertext buttons then offer two formats: a text-like ASCII format that can be imported into many spreadsheet softwares, or a binary Splus file. Clicking either button launches a file tranfer protocol (FTP) procedure that will transfer the selected data onto the user's computer, in a file whose location and name are to be defined in a pop-up FTP window.

Lastly, an ASCII version of the CORD on disk may be obtained from the corresponding author for researchers who cannot access the database on the Internet.

Acknowledgements: Technical assistance of $\mathrm{G}$. Alavoine, J.-L. Ballif, M. Boucher, C. Nice, O. Delfosse, D. Denys, C. and M.-J. Herre, M. Lauransot, F. and S. Millon, and P. Thiébeau is acknowledged. This work was supported by the Agence de l'environnement et de la maîtrise de l'énergie (Ademe), the Centre technique interprofessionnel des oléagineux métropolitains (Cetiom) and Inra (AIP Ecofon).

\section{REFERENCES}

[1] Bradbury N.J., Whitmore A.P., Hart P.B.S., Jenkinson D.S., Modelling the fate of $\mathrm{N}$ in crop soil in the year following application of ${ }^{15} \mathrm{~N}$ labelled fertilizer to winter wheat, J. Agric. Sci. (Camb.) 121 (1993) 363-379.

[2] de Groot J.J.R., Verberne E.L.J., Response of wheat to nitrogen fertilization, a data set to validate simulation models for nitrogen dynamics in crop and soil, Fert. Res. 27 (1991) 349-383.

[3] Denoroy P., Justes E., Modélisation du fonctionnement d'une culture de colza. État de l'art, Oléagineux Corps gras Lipides 2 (1997) 440-443.

[4] Diekkrüger B., Söngerath D., Kersebaum K.C., McVoy C.W., Validity of agroecosystem models. A comparison of results of different models applied to the same data set, Ecol. Modelling 81 (1995) 3-29.

[5] Gabrielle B., Modélisation des cycles des éléments eau-carbone-azote dans un système sol-plante, et application à l'estimation des bilans environnementaux des grandes cultures, Ph.D. thesis, École Centrale Paris, 1996.

[6] Gabrielle B., Bradbury N.J., Nicolardot B., Svendsen H., Smith J.U., Hansen S., Gosse G.,
Simulation of $\mathrm{N}$ dynamics in a rapeseed-cropped rendzina soil with the CERES, DAISY and SUNDIAL models, in: Proceedings of the 11th World Fertilizer Congress, 7-13 September 1997, CIEC, Gent, BL, 1997.

[7] Gabrielle B., Denoroy P., Gosse G., Justes E., Andersen M.N., Development, calibration test of a CERES-type model for winter oilseed rape, Field Crops Res. 57 (1997a) 209-222.

[8] Gabrielle B., Gosse G., Bilan environnemental du colza: premiers résultats expérimentaux, Oléagineux Corps gras Lipides 2 (1995) 443-444.

[9] Gabrielle B., Justes E., Denoroy, P. Modelling of temperature and nitrogen effects on the rooting dynamics of winter oilseed rape, in: Proceedings of the World Soil Science Congress, 20-26 August 1998, Montpellier, France, 1998.

[10] Gabrielle B., Kengni L., Analysis and field-evaluation of the \{Ceres\} models' soil components: Nitrogen transfer transformation, Soil Sci. Soc. Am. J. 60 (1996) 142-149.

[11] Gosse G., Cellier P., Denoroy P., Gabrielle B., Germon J.-C., Hénault C., Justes E., Laville P., Leviel B., Mary B., Nicolardot B., Recous S., Roche R., Bilan environnemental du colza, Tech. Report, Inra secteur Environnement Physique et Agronomie, Grignon, France, June 1997.

[12] Hansen S., Jensen H., Nielsen N., Svendsen H., The soil plant system model DAISY (basic principles modeling approaches), Tech. Report, The Royal Veterinary Agricultural University, Copenhagen, Denmark, 1993.

[13] Hénault C., Quantification de la dénitrification dans les sols à l'échelle de la parcelle cultivée, à l'aide d'un modèle prévisionnel, Ph.D. thesis, École nationale supérieure d'agronomie Montpellier, France, 1993.

[14] Hénault C., Devis X., Page S., Justes E., Reau R., Germon J.C., Nitrous oxide emissions under different soil and land management conditions, Biol. Fertil. Soils 26 (1998) 199-207

[15] International Benchmark Sites Network for Agrotechnology Transfer, Network report 1987-1990, Tech. Report, Univ. of Hawaï, Honolulu, USA, 1990.

[16] Leviel B., Gabrielle B., Justes E., Mary B., Gosse G., Water and nitrate budgets in a rapeseed cropped rendzina soil different amounts of fertiliser, Eur. J. Soil Sci. 49 (1997) 37-51.

[17] Ritchie J., Model for predicting evaporation from a row crop with incomplete cover, Water Resour. Res. 8 (1972) 1204-1213. 